\title{
ОСОБЛИВОСТІ ЕТНОКУЛЬТУРНОЇ ПІДГОТОВКИ МАЙБУТНІХ УЧИТЕЛІВ МУЗИЧНОГО МИСТЕЦТВА
}

\section{Лу Баовень}

здобувач третього (освітньо-наукового) рівня вищої освіти кафедри освітології та інноваційної педагогіки, Харківський національний педагогічний університет імені Г.С. Сковороди, Україна — Китай

У дослідженні представлені різні аспекти підготовки майбутніх учителів музичного мистецтва. Автором зосереджено увагу на варіативності підготовки майбутніх учителів до викликів сучасності але з урахуванням вікових традииій різних народів та етносів.

Ключові слова: майбутні учителі музичного мистецттва, етнокультурна підготовка, музика, здобувачі

The study presents various aspects of training future music teachers. The author focuses on the variability of preparing future teachers for the challenges of our time, but taking into account the age-old traditions of different peoples and ethnic groups.

Keywords: future teachers of musical art, ethnocultural training, music, applicants

Етнічна культура та музика це одні з основних рушійних сил розвитку будь-якої нації, тому якщо народ держави хоче розвиватися та досягати найвищих показників у розвитку людського потенціалу, у сучасних умовах. Поєднання цих двох рушійних сил розвитку людської особисті допоможе майбутнім вчителям музичного мистецтва

Етнокультурний компонент завжди входив у зміст уроків музичного мистецтва в школі у формі постійного звернення до народних пісень, танців, традицій, що значно збагачувало варіативність підготовки здобувачів. Наприклад, зміст уроків музики вчителя-музикознавця Д. Кабалевського [1] у середній школі будувався на етнокультурному принципі. Студенти слухали та осмислювали музику народів різних країн, розширюючи межі вивчення як рідної музичної культури, так і культури багатьох інших народів. Це особливо важливо для багатокультурної системи яка є у Китайській Народній Республіці (КНР), яка як відомо дотримується соціалістичого підходу у родові своєї державності та особливо освіти. Такий підхід відповідав ідеї розвитку дружби людей, відповідної принципам соціалізму [1; 3]. 
Сьогодні в Україні навчальні плани в закладах загальноосвітніх навчальних закладів дозволяють вирішити одне з актуальних завдань сучасної освіти і виховання. Це завдання - звернення до етнонаціональних, культурних традицій свого народу, рідного краю, формування інтересу та поваги до підростаючого покоління, толерантності до іншого способу життя та стилю мислення. Ці напрацювання можуть використовуватися у процесі підготовки майбутніх вчителів музичного мистецтва у КНР [3].

Вивчення національної музичної культури є важливою частиною музично-педагогічного процесу в навчальних закладах Татарстану, реалізуючи багатий виховний потенціал національного мистецтва та розв'язуючи проблеми етнокультурного розвитку здобувачів. У рамках професійної підготовки студентів Казанського університету читаються лекційні курси з етнографії та історії музичної культури, здійснюється розвиток національних музичних традицій у циклі вокально-хорових та інструментальних виконавських дисциплін. Твори місцевих композиторів включаються в навчальні програми 3 дисциплін фортепіанної підготовки (програма для класу основних і додаткових інструментів), «шкільні програми» (фрагменти уроків музики у формі лекційного концерту). Автори зазначають Глибокий розвиваючий потенціал фортепіанної літератури, дозволяє збагатитися національними музичними традиціями та надає широкі можливості для етнокультурного розвитку майбутніх учителів музичного мистецтва, формування їхньої особистої гуманітарної культури та професійних компетеностей [4].

Сюй Цзяюй, вивчаючи специфіку та сучасні тенденції етнокультурної підготовки студентів музично-педагогічних факультетів, виділяє такі найважливіші складові як: оволодіння й осмислення складових духовності, національно-виховних ідеалів та матеріальної культури народу; функціонування та застосування на практиці методів і засобів етномузичної педагогіки; здатність представляти та транслювати свою культуру в різноманітному середовищі світових етнічних культур; здійснення професійної діяльності з урахуванням полікультурного освітнього середовища. Слід зазначити, що запропоновані автором методи були спрямовані на формування професійної складової етнокультурної підготовки майбутніх учителів музичного мистецтва до роботи зі школярами. Серед них: комплекс прийомів імпровізаційної 
обробки музичних зразків; образно-демонстраційні методи, що забезпечують художнє ілюстрування словесних пояснень, музичних колоквіумів та вікторин; групи словесних та емпіричних методів; бінарні методи; метод порівняння різних інтерпретацій твору, аналіз засобів виразності та визначення етнокультурного потенціалу [2]

Таким чином, можна зробити висновок, що до особливостей етнокультурної підготовки майбутніх вчителів музичного мистецтва можна віднести: змістовну етнокультурну підготовку у процесі їх навчання, вивчення різних аспектів та особливостей розвитку етносу для якого викладається музичне мистецтво, готовність до імпровізації у процесі навчання здобувачів.

\section{Список використаних джерел:}

1. Кабалевський Д. Основные принципы и методы методики по музыке для общеобразовательной школы. Москва : Просвещение, 2007. С. 8-15

2. Сяй, Цзѐяй. Методичні засади етнокультурної підготовки майбутніх учителів музики у процесі фахового навчаннѐ. дис. ... канд. пед. наук: 13.00.02. Київ, 2017.

3. Bukhnieva O., \& Bankul L. Ethnocultural Aspects in Professional Training of Music Art Future Teachers. Journal of Danubian Studies and Research. 2020. Vol. 10, No. 1. pp. 166-171

4. Salikhova L., Batyrshina G., Safiullina L., \& Abdirakhman G. Ethnocultural Development of Future Music Teachers in Process of the Tatar Piano Music's Studying. Journal of History Culture and Art Research. 2017. 6(6). pp. 159167. https://doi.org/10.7596/taksad.v6i6.1336 